\title{
Enclaves, Insecurity and Violence in Karachi
}

\author{
Sobia Ahmad Kaker
}

\begin{abstract}
This paper analyses conditions of insecurity and violence in Karachi in relation to an emerging geography whereby the city is fragmented into various enclaves of business, leisure, and residence. Although enclavisation is largely viewed as a response to heightened urban crime and violence, the paper argues that sociopolitical conditions generated by processes of enclavisation themselves create circumstances that generate a continuum of violence. Qualitative data from two selected residential enclaves within Karachi illustrate the argument. The experience of residents, visitors and workers within the two enclaves is relationally reviewed within the context of urban politics in Karachi. The conclusion highlights the agency of urban space in structuring conflict in Karachi by exacerbating differences, heightening vulnerabilities, and reconfigurestate society relations.
\end{abstract}

Keywords: urban governance; insecurity; enclavisation; urban conflict; urban space; community organisation; neighbourhood association

\section{Introducing Violence, Insecurity and Enclavisation in Karachi}

With a murder rate as high as 13.49 per 100000 in 2012, ${ }^{\mathrm{i}}$ Karachi has been branded one of the most dangerous cities in the world. ${ }^{\text {ii }}$ The city of 18 million residents is frequently victim to conflict and insecurity. Politically motivated targeted killings have intensified, as have terrorist and gang related violence, and everyday crimes (burglaries, robberies, muggings, kidnappings, vehicle snatching). ${ }^{\text {iii }}$ An Rafia Zakaria reported in a Dawn Newspaper article on February 10, 2010, the situation is complex and it is difficult to cleanly separate the activities of organised crime, land mafia, labour unions, and ethnically oriented political groups. The violence is also hard to label. Various analyses point to a myriad of different motivations: as a contest between different mafia groups over a share of the city's resources; an outcome of the violent tactics used by armed wings of political groups employed to create or shape constituencies (such as land grabbing, evictions and settlements); a political tactic to disrupt the economic flows from the city and hence injure the national economy in order to bargain with the federal government; and an outcome of informal networks that emerge as a basis of contract enforcement in the absence or failure of formal systems of contract enforcement. ${ }^{\text {iv }}$

In recent years, the fallout of the 'War on Terror' has also been increasingly felt in Karachi. Though the theatres of the war are located in a geographically distant part of Pakistan, its repercussions are felt in Karachi. Since 2001, Taliban groups have attacked multiple targets in Karachi: State security forces, army installations, US and NATO supplies, foreign consulates, five star hotels, mosques and shrines, and religious and political processions. The victims of these attacks are mostly ordinary urban residents. Between 2007 and 2012, 1360 people have been killed in terrorist attacks (suicide bombings and sectarian killings), and more than 2209 have been injured. v More recently, 
various local news articles report that Taliban groups have entrenched themselves within various pockets in the City, swelling the ranks of existing criminal and mafia groups. In some cases, they have also created their own syndicates to generate revenue for terrorist activities.

In this situation, various informal settlements around the city have come under scrutiny. They are considered safe havens for terrorist groups seeking cover through the informal networks that these spaces are organised along. Many of these settlements have become 'no go areas' for police and security forces. In an article published in The Guardian, on February 16, 2010, Declan Walsh described such spaces as breeding grounds for militant political activism, and as potential hiding places for Al Qaeda operatives. The conflict along the Af-Pak border has displaced Pashtuns from Waziristan into Karachi, and most of these migrants are viewed suspiciously for having links with Taliban. The entry of in-migrants from these places has also affected the balance of power between two political groups (ANP and MQM) who mobilise support on an ethnic basis with violent consequences. In most cases, heterogeneous unplanned settlements have become hotbeds of violence, as one group tries asserting influence over the other.

This violence and fear of violence has had a tangible effect on Karachi's landscape. Failures in provision of public safety have increased the popularity and demand for private security and community policing across the urban landscape. ${ }^{\mathrm{vi}}$ A combination of guards, walls, barriers, razor wires, checkposts, and patrols combine to form a security architecture that prevails across most urban spaces in Karachi today. Fortified enclaves now encompass spaces of leisure, business, and residence. These security measures are a physical manifestation of the enclavisation process, though it is not complete without particular practices, norms, and codes of conduct which govern access and in-access to such spaces. ${ }^{\text {vii }}$

Current discourse on enclavisation and enclaved cities is not well linked with discourse on violent megacities. There are references to enclosures and fortifications in violently divided cities across Africa and Latin America, and the Middle East. These protective architectures are attributed to rising levels of urban violence, insecurity, crime and fear of crime. ${ }^{\text {viii }}$ However the analysis falls short of delving into the politics of space to create a relational understanding of enclavisation and violence. Literature on urban violence in megacities of the global south points towards the reinforcing, selfperpetuating nature of urban violence. ${ }^{\text {ix }}$ According to Perlman, if the state is impotent in the city, and absent in the favelas, the contests over right to the city become more pressing, locking urban residents, especially the poor in a cycle of violence. ${ }^{\mathrm{x}}$ Field work in Karachi demonstrates that such conditions arise through enclavisation. Affluent areas are securitized, and urban poor are subjected to state-led violence. Increasing marginality breeds inter-communal and personal violence, perpetuating structural and political violence in 'chains, spirals and mirrors' or the 'continuum of violence'. ${ }^{\mathrm{i}}$ Thus, I argue that by creating conditions that engender structural violence, enclavisation perpetuates violence that is manifested by the politics of control as well as repressive state policies.

The intermingling of the landscapes of 'everyday life' and 'international relations' have also resulted in increasing the prominence of local culture and social geography in global security. ${ }^{\text {xii }}$ Especially following the War on Terror, there is an increased interest 
in controlling 'ungoverned spaces'. As Graham suggests, cities are increasingly prominent as sites where geopolitical strategies play out. ${ }^{\text {xiii }}$ The sprawling megacities of the global south with are termed 'feral' xiv particularly for the risks they present to global security. Complimenting this stance, international development agencies progressively foreground security as a prerogative that showcases 'good governance'. ${ }^{\mathrm{xv}}$ This provides impetuous for local governments to use security in order to invoke a special kind of politics where repression and states of exception are normalised. In Karachi too, enclavisation is often encouraged on these grounds. Though lacking capacity themselves, municipal authorities as well as police departments encourage organisation at the neighbourhood level for deployment of private security. Enclosures are facilitated and permitted in order to provide an effective solution for tackling the security situation.

However, this encouragement to securitise and privatize space is selective: affluent areas are assisted, while similar enclavisation and privatisation in low income areas is viewed negatively. It is seen as strengthening of non-state actors and mafia groups, and hence a threat to urban security. ${ }^{x i}$ In low income settlements, local organisation is often the first step to political bargaining. The emergent community leaders often negotiate votes in exchange for public works within the settlement and the politics of patronage is often tied to political mobilisation. This situation is perceived as especially troublesome by state actors because Karachi's security situation in deeply linked to crisis on local and national governance. Violence is readily deployed in and between ethnic enclaves by heavily armed and politically charged residents, and often becomes a negotiation point between differing political parties at different levels of control.

This literature provides a background for examining emergent enclaves in Karachi. As pointed out earlier, existing literature cites enclavisation as a strategy to counter heightened urban insecurity and conflict. I would add another layer to this argument and suggest that enclavisation itself creates conditions which intensify tensions in urban space. The very processes tied to ensuring protection and security perpetuates urban violence.

This argument is a purposeful shift from current discourse on violence in Karachi which essentialises informality, ethnic politics, and migrant settlement as root causes for urban conflict. ${ }^{\text {xii }}$ I do not refute or discredit these arguments, but instead present an alternative analysis foregrounding the agency of urban space in understanding conflict in Karachi. I argue that the division of the city into guarded enclaves plays a critical role in magnifying socio-political divisions in Karachi and shuffling structures of urban governance.

This paper therefore suggests that conflict and violence in Karachi are manifestations of tensions that arise as urban residents are subjected to relational processes of enclavisation across the city. To support this claim, I use empirical evidence from two residential enclaves, Clifton Block 7 (an upper middle class gated community) and Sultanabad (a homogenous low income gated community in a slum settlement). The evidence is based on extensive qualitative field research which focuses on the politics of everyday life within enclaved spaces in relation to the city 'outside'. Empirical analysis demonstrates how enclaves are spaces of subjectivity that create paradoxes of security 
and insecurity, and generate vulnerabilities of inclusion and exclusion. I also demonstrate how such enclaves emerge as urban political actors which shift existing state-society relations. In conclusion, recount why enclaved urbanism in general and enclavisation in Karachi in particular is relevant for understanding urban conflict and violence.

\section{Understanding Enclaves through the case of Karachi}

The dictionary of human geography defines an enclave as 'A small piece of territory that is culturally distinct and politically separate from another territory within which it is located...(..)....The term is increasingly used to refer to a city neighbourhood displaying distinctive economic, social and cultural attributes from its surroundings.' xviii Various authors providing empirical evidence of residential enclaves describe them as inward looking spaces which range in architectural form between bounded and open. ${ }^{\text {xix }}$ These are mostly privately governed spaces that aim to restrict circulation of 'unwanted' elements through security mechanisms, membership procedures, or cultural practices. Such enclaves- whether gated communities, enclosed neighbourhoods, or ethnic enclaves- exhibit a unique political space because they are exclusionary spatial communities that are governed through distinct juridico-political structures. ${ }^{\mathrm{xx}}$ Enclaved spaces have often been explained within the framework of Agamben's paradigm of the camp. ${ }^{\text {xxi }}$ Such spaces are organised on values of extreme vulnerability in the face of high social control.

As a phenomenon that is spread over most global cities, residential enclaves have gained significance in current scholarship. As Graham and Marvin suggest in their splintering urbanism thesis, enclaves materialise to facilitate circulation of goods, people and information within a secure environment. ${ }^{\text {xxii }}$ Such processes may be propelled by colonial histories of urban fragmentation, current trends of globalisation and deregulation, imperatives of securitisation; or a combination of these factors. ${ }^{\text {xxiii }}$ In creating safe havens in cities where crime and fear of crime is extremely high, enclaves result in shrinking public space, stifling democratic interaction and heightening contests over space. ${ }^{\text {xxiv }}$ Enclavisation is contentious in all of the cities where it has been studied. Enclaved spaces have been compared to a new form of apartheid, ${ }^{\mathrm{xxv}}$ have been marked as sites that spatialise biopolitics, ${ }^{\mathrm{xxvi}}$ build a climate of fear, ${ }^{\mathrm{xxvii}}$ and perpetuate social segregation based on socio-economic differences. ${ }^{\text {xxviii }}$

This brief literature review supplies a background to enclavisation in Karachi. Field work in Karachi shows that the typologies of enclaves vary: they are not all bounded spaces, but each generates a distinct politics of space based on its particular genesis. The recently barricaded foreign consulates in Clifton and DHA, as well as places like the Governors House, Sindh Assembly, Sindh High Courts etc. show that not all securitised enclaves are built as such, but evolve into enclaves because of an increased threat of violence. In some cases, enclaves may be previously bounded spaces governed through distinct governance structures. The various cantonment housing schemes such as Askari, Karsaz, and Malir are examples of such kinds of enclaves. In others cases, enclaves may be privately enclosed public neighbourhoods such as the recently enclosed streets in Mohammad Ali Society, KDA Scheme 1, Lalazar, and Clifton Block 7. Yet another type 
is the space created in the form of no go areas that are common in many of the city's sprawling low income settlements.

For the purpose of illustrating my arguments, I will focus on two of these types of residential enclaves: an enclosed neighbourhood (Clifton Block 7), and Sultanabad, a low income settlement that has ethnic enclaves within it. I have developed the case studies through qualitative field research conducted in Karachi over a period of six months between June 2011 and September 2012. For the purpose of this paper, data collected through personal observations of sites and unstructured interviews ${ }^{\mathrm{xxix}}$ is presented to critically interrogate enclavisation and its relation to urban politics in Karachi. The relationship between enclavisation, governance and security will be investigated through an examination of the processes of enclave formation, and emerging social relations between and amongst residents, visitors and other users.

\section{The elite neighbourhood: Clifton Block 7}

Clifton Block 7 is an ordinary neighbourhood housing affluent Karachiites which is currently undergoing enclavisation. It streets, which are public property, have been recently enclosed so as to restrict circulation of non-residents. Access is restricted through street barriers placed at all entry and exit points. The barriers are open from $5 \mathrm{am}$ to $10 \mathrm{pm}$, and closed through the night. Private security guards sit by the barriers to review those wishing to enter. CCTV cameras are also strategically placed at these points to supplement the guards' gaze.

The enclavisation process in Block 7 started in 2007 as an initiative to solve common neighbourhood issues which were not restricted to security. Residents along one lane of Block 7 were adversely affected after heavy rains in Karachi flooded a nearby storm water drain, causing it to overflow into their streets. When individual attempts to get the municipality to respond to the problem failed, a few people organised themselves to form Clifton Block 7 Resident's Association (a registered legal entity). As its first task, the association lobbied with the department for local government municipal services to drain out stagnant water and get their streets cleaned up. Following its success in engaging the municipality, members decided to expand the charter of the association to other matters of collective concern, and increase memberships to add weight to their demands on the municipality. Amir, the president of the association reported that it was an uphill task to get more residents on board, particularly when the association attempted to expand its agenda to include costly collective security. Today, the association boasts more than 200 members, each of whom contributes financially (by way of a fixed monthly tax) towards costs. This tax funds the fee for security staff, salary for the association's hired area manager, ${ }^{\mathrm{xxx}}$ and other development initiatives.

So far, the association has been successful in bargaining with the city administration on issues of collective security and premium municipal service delivery. The city administration has granted the association permission to enclose the neighbourhood, and has agreed cooperate with Block 7 in its private initiatives at apprehending potential and suspected criminals. The neighbourhood has also been granted municipal funding for road carpeting, park development, and installation of street lights. Other initiatives for neighbourhood improvement and security, such as sign-posted 
street numbering, repair of street barriers, and installation of CCTCV cameras have been funded through private and corporate sponsorships. ${ }^{\text {xxxi }}$ Sajid, a resident, is very pleased with the outcomes of enclavisation: "Our children can cycle freely in the streets, we no longer constantly worry about being followed home by potential muggers, and our property values have risen after the associations' initiatives- everyone wants to live in a clean, safe environment!”

These neighbourhood development and improvement projects have been mostly successful with help of volunteers who have consistently worked to develop links between their neighbourhood and various other governing bodies such as the town administration (municipal department), and public works organisations such as the Karachi Electric Supply Company (KESC) and the Karachi Water and Sewerage Board (KWSB). The goal is to ensure better public service delivery through an efficient service management and complaint system. The Town Administrator commends this private sub structure of local municipal service provision: "With people taking ownership of their neighbourhood, Clifton Block 7 is emerging as a model neighbourhood which the city government can claim credit for. In an environment where it continuously faces critique for its failures, the successes of Block 7 as a clean, well-functioning and secure neighbourhood allow the city government to gain political support and credibility.”xxxii

Residents also report that this newly emerging civic and community spirit has improved their lives to a great extent. The cleaner and more secure neighbourhood has had economic benefits for home owners, as property values in Block 7 are increasing. However, some residents are opposed to the associations' work and remain non-members. They do not pay the monthly contribution to the association because they do not support the enclosures and security initiatives within the block. For Natasha, non-membership was a non-issue. "I don't really know of the association and its activities" she said. "I know the Ismaili community has gotten together to work for their own welfare- they do look after each other . . . but I do think they are selfish. My friend who had a break in recently asked to see CCTV coverage and they refused!” Natasha felt that the association was exclusionary by nature because the majority of members belonged to a minority religious community known to be tight knit. However, non-membership is taken seriously by contributing members who argue that the association is for all residents irrespective of faith, and that non-members are purposeful free riders. "You should smash their cars, threaten them!" says Jamal, an aged member who feels angry that those who don't 'pay up' free ride at his monetary expense. Amir, the president of the association also expresses his frustration over the involuntary inclusion of non-members to a cleaner, safer environment. "I strongly feel that if they (non-members) complain or seek help from the association for any municipal issue, the association should refuse it so that they are made to feel helpless," says Azim. "I have told my security guards to out-rightly reject security assistance if requested by non-members”.

The contacts and relationships developed within the municipal government by the Clifton Block 7 association are often exploited to push non-members to submit into membership. Amir highlights that public service agencies (water and sewage, electricity, gas) are encouraged to refuse service unless with the recommendation of the association. Such tactics to create distance between residents and governance agencies ensures that 
the Block 7 Residents Association becomes a powerful mediator between the two. The quest for more efficient service delivery on the part of municipal agencies, and the need to divert public policing resources to other security imperatives combine to encourage a shift in the burden of responsibility for provision of public goods towards private actors. The processes of enclavisation thus shift the social contract in ways that devolve state power to privately organised committees such as the Block 7 Association.

The tensions between members and non-members within the Block make evident how enclaved spaces create paradoxes of inclusion and exclusion, and security and insecurity. These are heightened by rules and regulations concerning use of public space. Service providers and domestic workers are not allowed into parks at certain times of the day and are discouraged from 'loitering' around in the streets. These limitations are placed to produce a sanitised space where children can bicycle on the streets, neighbours mingle in the park, and there is no fear of crime and insecurity. Yet, service providers that often live and work within the premises resent these biases. Akmal -a domestic help in one of the houses in Block 7- finds these rules contradictory. "That guard who says I shouldn't sit in the park, who is he? He is me wearing a uniform, getting paid to push people who look like him off!” Other than restrictions on movement in leisure hours, domestic service workers also resent criminalisation. As Farzana says, "just because a few servants commit crimes, we all have to bear the brunt. They (employers) trust us to watch their children, look after their house, but would easily hand us over to the police if someone robs them.”

Farzana's comments deriding her employers' paradoxical sense of simultaneous trust and insecurity are reflective of the wider neighbourhood enclave. The inclusion of security guards within the security architecture of enclaves generates insecurities for residents and managers. "I don't like the idea of these guards watching me all the time. I feel more insecure knowing that they are aware of my movements and daily pattern," says Samina, a resident. The system of surveillance however turns in on itself in multiple ways. While showing me the CCTV control room, Amir proudly says that "we tell our guards these cameras are watching them too- lax behaviour or involvement in criminal activities on their part would be seen immediately." The very guards who perform security for the enclave are regarded as potentially risky bodies. They may be part of the enclaves security infrastructure, but they never truly belong within the enclave. Security guards, along with other service workers are simultaneously places inside and outside: they are bound by rules governing life within, but do not enjoy benefits of membership.

Enclaved space thus produces also produces paradoxical subjectivities along binaries of inside and outside, included and excluded, and security and insecurity. In Clifton Block 7, the enclavisation process both cements and fractures the neighbourhood, and creates relations of power and disempowerment between different users of space. Parts of the neighbourhood have solidified as a community after a breakdown of municipal services. After successes in its collective endeavours, the association slowly constructed a space that is more in line with private ideals of urban life by regulating the usage of space for residents of the neighbourhood. While non-members enjoy the benefits of this privatisation, they are made to feel more excluded in times of crisis and breakdown, where even public agencies become inaccessible. Others excluded are the 
numerous domestic workers such as maids, house guards, and chauffeurs. While living and working within the enclave, they are treated as 'outsiders' and are subjected to stringent security procedures and discriminatory rules and regulations. In enclaves such as Clifton Block 7, therefore, marginalised groups are pushed into a state of exception. Those excluded have no voice nor representation within the space produced.

\section{The marginalised settlement: Sultanabad}

Sultanabad is a densely populated inner city squatter settlement situated within Karachi's security red zone. Most residents are low income service workers (house help, guards, and chauffeurs), or shop assistants and clerks who work in houses, offices and hotels in the vicinity. Current approximations place the population to be 70,000 persons, with the average household size being 7 to 8 persons per household. ${ }^{\text {xxxiii }}$ The majority population is ethnic Pashtun (approximately 60\% of the population), while other ethnic groups such as Hazara, Mohajir, Sindhi and Balochi's also live in the settlement. ${ }^{\text {xxiv }}$ There is also a small population of migrants originating from Gilgit-Baltistan (Baltis), and these are clustered in a single neighbourhood. Sultanabad is thus ethnically heterogeneous, though there are homogenous spatial clusters within it.

Karachiites regard Sultanabad as an enclave. Despite not being walled and gated, its physical and imaginative geographies give the area an enclave-like quality. This sentiment was echoed by Amir (president of the Block 7 Association) who regarded Sultanabad as a strategically located labyrinth where "criminals enter to lose hot trails of pursuit”. The few wide inroads from the main road don't fully penetrate or cross through the settlement, thus restricting entrants who don't have business within. Regular news reports of violent riots, murders, and shootings amongst residents and between residents and police have added to Sultanabads reputation of being a lawless place. In fact, in a recent news article published by Dawn News March 31, 2013; parts of Sultanabad have been reported to be no go areas controlled by Tehrik-e-Taliban Pakistan (TTP). The mazelike quality of internal streets makes surveillance impossible, and there are some areas within Sultanabad that are off limits even for police and security forces. There have been incidents when police have been driven out by force, and officers of special security forces have been violently attacked. ${ }^{\mathrm{xxx}}$

With this reputation in mind, I ventured into Sultanabad with trepidation. I gained entry through a local ex-union councillor who walked me through the settlement and introduced me to various locals. Personal observations and interviews from repeated visits confirmed that residents were extremely mistrustful of people from 'outside' visiting their neighbourhood. ${ }^{\text {xxxvi }}$ Interviews revealed that this paranoia was a combination of fear of random shootings or targeted killings by outsiders at times when the city's violent ethnic politics flared up, and also fear of harassment from police and security forces. "We have to take our security in our own hands", says Nishat, a resident and political party worker. "Political workers are routinely targeted by killers hired by rivals. If we don't recognise any men walking around, we check their ID cards for ethnic affiliation to determine their loyalties. If they look like trouble, we ask them to leave immediately for their own welfare.” Ordinary residents agree that the source of violence is often from within the settlement. Yet they feel the police can never provide protection. 
Kamal, a Pashtun who has lived in Sultanabad for over 40 years says "We are helplessthey (the new pashtun migrants into Sultanabad) are drug addicts with a backward mentality. They steal, beat our children up for no reason, and have brought a rural culture to this place. We don't support this talibanisation. But we can't trust the police eitherwe have no faith in their integrity."

To combat the regular threats to life and property from within and outside, residents of Sultanabad resort to their own version of Enclavisation. Karachiites living outside Sultanabad deem the whole settlement an enclave, yet Sultanabad is further fragmented into various enclaves. The multi ethnic settlement is split into loosely organised ethnic clusters which look after resident/community interests. These clusters take the form of a mohallah- i.e. a traditional tightly knit spatial community. Some Mohallah's in Sultanabad (such as the Mehsud Mohallah and Balti Mohallah amongst the many others) are even restricted for other residents of Sultanabad. The Mehsud Mohallah is not walled or gated, residents are violently protective of their turf. Habib, a worker at the community health centre, narrated an incident where the process of widening a road to allow ambulances to cut across Sultanabad was halted just outside the Mehsud Mohallah. "As soon as we got close to the Mehsud Mohallah, men came out with guns, threatening to shoot us if we continued forward."

Another enclave within Sultanabad, the Balti Mohallah, is actually walled and gated. The Balti Mohallah is one of the most tightly organised ethnic clusters in Sultanabad. Matters of community life are overseen by a voluntary association. The association is presided over by Imam, a community elder respected for his prowess over religious and legal issues. According to Imam, the association works towards "ensuring the welfare of the population by providing security and structural development in the Mohallah in exchange for loyalty and obedience". The arrangement suits most residents who have confidence in the association's decisions. "The elders know what's best for us," says Qaiser, a resident. "We are not allowed to sell or rent our property without their approval; they want to make sure this remains a Balti or at least Shia Mohallah. It is for our own protection.”

The Balti Mohallah has been recently enclosed as defence mechanism against the neighbouring Pashtun areas which house "gun toting tribals with a Taliban mindset. The narrow steel gates placed at entry and exit points are locked from 11pm to sunrise. Night time security is supplemented by patrol; guards are hired from within the community. Despite these measures, residents continue to face threats. "The other day, two armed Pashtun men came into our Mohallah, taunting us, mocking us for being Shia muslims,” narrated Majid, a young Balti student. "They threatened that if we don't vote for the Awami National Part (ANP), we would suffer. Our elder sorted it out, I think. He's well respected in Sultanabad...that is why he is our leader." The incident Majid spoke of was confirmed by the Imam. "These stupid children are full of hot air. I recognised them, and complained to the elders in their community of their behaviour. They were made to apologise soon enough, and that was the end of the matter.” When I asked Imam as to why he was heard, and on what basis he was able to offer protection to his community members, the answer was simple. "We are 300 votes," said Imam. "Everybody in our 
community -men, women, and young adults- are registered voters. We may be a minority community, but our voting power adds weight to our numbers.”

This incident highlighted the micro-politics of everyday life in Sultanabad. Enclavisation is a necessary tactic to ensure protection. However, the case of Sultanabad shows how enclavisation is not just about walling and gating. The process is essentially tied to community cohesion and collective bargaining. Voting as a block ensures protection, and this enfranchises local community elders with respect and voice within the wider community. More importantly, processes of enclavisation encompass governance of everyday life in a violent settlement. Community affairs are managed by 'elders' who are respected as community representatives to act on residents' behalf. The community elders are not elected, but are appointed because of their influence over their community. They are tasked to build strong relationships with other elders within the settlement, as alliances are necessary for matters such as dispute resolution and infrastructural development work.

For example, grievances in Sultanabad are settled through a 'jirga system'. This is a traditional dispute settlement mechanism which tasks adjudication to respected community elders who are trusted to act in neutrality to both complainant and defendant. Residents in Sultanabad express more confidence in this traditional system for dispute resolution as compared to the legal system. Irfan, a clerical officer at the Karachi Port Trust prefers the Jirga system because he feels that "the courts are inaccessible, inefficient and unjust- everyone knows that judges award decisions to the party with deeper pockets! It takes months, sometimes years to get a judgement. The Jirga decides cases within a few weeks!”

Similarly, elders also play a significant role in shaping their mohallah's relationship with other communities in the settlement, dictating which local political candidate to support, and which particular groups to befriend or avoid. These decisions are usually outcomes of negotiations between various Mohallah elders, keeping in mind outcomes that would be beneficial for the community. For example, Imam, the community elder of the Balti Mohllah spoke of his alliance with Khattak, a popular community elder in Sultanabad as stemming from an understanding that "Khattak has ties with political groups who have done extensive development work in Sultanabad. He is progressive, open minded, and is well connected to people in power (in the city government). We usually follow his advice on voting and fully support him.”

These interviews also suggest that enclaves in low income settlements are more than just spatial communities offering protection to marginalised urban residents. In the case of Sultanabad, they are politically charged spaces which empower people largely abandoned by the state. Residents within Sultanabad are aware of their political clout, and exercise their democratic freedoms often. They are quick to organise political rallies and participate in disruptive riots in order to negotiate their terms for ensuring order and acquiescence with the city and state governments. ${ }^{\text {xxxvii }}$ The strength of their collective votes makes Sultanabad a settlement hard to ignore for local politicians vying for power.

Thus, the case of Sultanabad highlights how the juxtaposition of neighbourhood/local and government/state politics results in a complex reorganization of citizenship and state-society relations. However, although the political spaces opened up 
through enclavisation aid in securing residents, the resulting political space also creates tensions and perpetuates conflict. While enclave residents benefit from increased democratic voice and better access to lower tier political representatives, this voice is collective in nature, and is mediated through the leader of the community association. This increases the power of the leader in relation to individual members, almost to an autocratic level. Moreover, this vote politics results in increasing vulnerabilities for those not eligible to vote, as they are unable to find protection or representation. This is true for a few minority Christian families living on rent in one of the Mohallah's in Sultanabad. "We are renting tenants, and are not registered to vote within Sultanabad" says Asma "that is why they don't care about us. I keep going to the elders here to complain of young boys who rough handle my sons and daughters whenever they come home from work at the end of they, but no one cares about us.” As absolute minorities within the enclave and the rest of the settlement, families like Asma's may live within enclaves, but live outside its political spaces. They do not capture the interest of any prominent 'elders', and it becomes apparent how the political structure of such enclaves reduces the marginal to levels of absolute vulnerability and despair.

\section{Critically Revisiting Enclavisation and Violence in Karachi}

The above case studies attempted to place enclaves in the context of wider disruptive events in Karachi. Ethnic division, infrastructural failure, and a negligent state allow for conditions under which enclave creation becomes a solution and a tactic to deal with crisis of governance, insecurity, and disruption in everyday urban living. The examples of Clifton Block 7 and Sultanabad showcase different types or enclaves, each with a distinct environment, context and urban form. Yet, they also showed commonalities. In Block 7, enclavisation embodied a rejection of public spaces and public services, which were deemed as insecure, disorderly and chaotic. On the other hand, in Sultanabad enclaves emerged as exceptional spaces towards which the state felt no obligation. In both cases, social organisation and collective action became the first step to privatisation of space. Within this privatised space, public spirit was stoked. Political engagement and social networks were used to negotiate everyday life.

At a micro-level, enclavisation results in re-ordering private and public space. As urban space is increasingly privatized and homogenized, seeds of differential are also sown. The distinct politics of space is thus ordered on lines of difference, which is spatialised. Although Gupta and Ferguson ${ }^{\text {xxxviii }}$ argue that notions of culture and community can no longer be fixed to a territory because of the de-territorialized nature of urban interactions in mega-cities, the production of enclaved spaces brings territory squarely back in discussions of identity, difference and conflict. The production of enclaved space reconfigures notions of rights, access, community and belonging. These affectual binds become stronger and more fixed with the discursive and performative aspects of the enclave, and resulting tensions in space and circulation lead to conflict between 'outside' and 'inside'.

Moreover, it is also evident that such a politics of exclusion exacerbated marginality for more vulnerable residents and users of space. As suggested feminist 
theories of difference suggest, identity formation is viewed as a construct and articulation of a more dynamic process of representation, signification and performativity which is intertwined with the material conditions of everyday life. ${ }^{\text {xxxix }}$ These critical perspectives on difference lead one to understand that the relational processes of enclavistion construct racialised identities. This process is embedded in frameworks of power, and the subject is seen as socially constructed. This is linked with Judith Butler's theory of performativity, where naming is an identity constituting performance. This is elaborated as an attribute of power that uses discourse to establish a criteria of identification through which the subject then comes to be known. Grounded in structures of governmentality, institutions and relational frameworks of power, such discourses not only create subjectivities but also determine their rights and privileges. ${ }^{\mathrm{xl}}$ Emerging enclaves constitute identities of different social groups: the affluent as safe, the poor as risky, which then govern issues of rights and access within and between urban enclaves.

Enclaves therefore are highly political spaces. Not only do they create various subjectivities, but they also delineate a fractured urban polity. The two case studies presented show emerging forms of citizenship are fragmented and splintered in enclaved spaces. Organisational forms produced by such enclaves- in these cases the Clifton Block 7 association, and the various elders guiding communities in Sultanabad- displace the social contract and hence re-configure state-society relations. This is echoed by Alsayyad and Roy ${ }^{x l i}$ who emphasise that the changing forms of citizenship in enclaved cities are reminiscent to medieval times by being 'linked to either patronage (as in the bishop) or to associational membership (as in the guild) and in both cases it is fundamentally about protection... such forms of citizenship substitute for or are even hostile to the state. ${ }^{\text {xlii }}$

The fact that all such enclaves in Karachi create conditions of possibility of hostility towards the state is largely ignored by the city's government. Fieldwork in Karachi shows that the state has its own selective biases towards enclavisation: affluent areas such as Block 7 are assisted, while similar enclavisation and privatisation in low income areas is viewed negatively by state authorities. In low income groups, the process is thought to strengthen non-state actors and mafia groups, and is hence considered a threat to urban security. State representatives do not consider how resulting structures of governance that emerge through processes of enclavisation in affluent as well as poor areas equally appropriate governmentality from state institutions.

Nor do they recognise that processes of enclavisation are relational, and its ties with violence and insecurity are circular. When elite enclaves criminalise the urban poor, police brutality and state violence is pushed into low income settlements. Increased marginality and insecurity push poor urban residents towards protection racketeers or prominent elders who secure residents from a repressive state. In ethnically heterogeneous settlements, violence is exacerbated by the very political sociology of enclaved urbanism. Community organisation, vote politics, ethnic affiliation, and power and politics combine to form a heady mix that explodes in violence. This is supported by evidence from Karachi which suggests that community associations can easily morph into violent, ethnocentric bodies. ${ }^{\text {xliii }}$

This paper merely serves as an introduction to a broader research agenda that studies how the division of Karachi into enclaves creates a crisis of security. In a city 
where ethnicity, language, religious beliefs, and political affiliation are all potentially volatile markers of identity, this paper tries to argue that enclavisation adds another dimension to identity construction. Similarly, both cases highlight how enclaved space produces subjectivities through notions of inside and outside, and security and insecurity; simultaneously generating marginality as well as empowerment. Finally, I have argued that the relational nature of enclavisation makes it is impossible to separate the violent consequences of enclavisation from the violence and insecurity which pushed the process in the first place.

Thus, it can be assumed that this kind of urban form generates a continuum of violence: Enclaves emerge as a tactic to deal with insecurity, while at the same time causing contests in space which result in perpetuating violence. In this way, urban space itself is agential in generating conflict and violence in the city.

\section{Acknowledgements}

I am extremely grateful to Steve Graham and Martin Coward for their supervision, which has been instrumental in shaping my work and developing my thoughts. A special thanks to Martin for his very useful comments on an earlier version of this paper. I am also thankful to the two referees for reviewing this article. All errors remain my own.

\section{Notes}

${ }^{i}$ Authors calculations from data available with the Citizen Police Liaison Committee and Sindh Police.

${ }^{\text {ii }}$ Mercer, Quality of Living Worldwide Rankings

iii Dawn Newspaper archives, June 2010 to June 2013

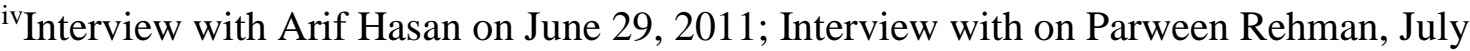
19, 2011; also see Budhani et al., " The Open City: social networks and violence in Karachi”; Gazdar et al, "Informality and political violence in Karachi."; Gayer, "Guns, Slums, and" Yellow Devils": A Genealogy of Urban Conflicts in Karachi, Pakistan."

${ }^{v}$ Pakistan Institute of Peace studies, available online at URL: http://sanpips.com/index.php?action=reports\&id=tml2

vi Interview with Sharfuddin Memon (security advisor to Sindh Home Minister) on May 9, 2012

vii The broader project currently undertaken by the author critiques existing literature on enclaved urbanism for being underdeveloped and under theorised. This argument is beyond the scope of this paper and will be addressed in forthcoming articles. For the purpose of clarity and simplicity, a basic understanding of the concept of 'enclaves' (as found in current literature) is used in order to accurately analyse urban space within enclaves.

viii See for example Claire Benit-Ghaffou, "Unbundled Security Services and Urban Fragmentation in Post-Apartheid Johannesburg"; Caldiera, City of Walls

ix See Koonings and Kruijt, eds, Fractured Cities

x Perlman, "Megacity's Violence and its Consequences in Rio De Janeiro." p. 62 
${ }^{x i}$ Scheper-Hughes and Bourgois, Violence in War and Peace. P.1

xii See Ingram and Dodds, Spaces of Security and Insecurity.

xiii Graham, "Postmortem City: Towards and Urban Geopolitics."

xiv Norton, "Feral Cities."

${ }^{x v}$ Ingram and Dodds, Spaces of Security and Insecurity: Geographies of the War on

Terror.

xvi Interview with Sharfuddin Memon (security advisor to Sindh Home Minister) on May 9, 2012

xvii Gayer, "A Divided City"; Waseem, "Ethnic Conflict in Pakistan: The Case of

MQM." Budhani et al, "The Open City”

xviii Gregory et al, eds, The Dictionary of Human Geography. p. 191

xix See for example Glasze, et al, eds, Private cities: Global and local perspectives;

Lemanski et al, "Divergent and similar experiences of 'gating' in South Africa:

Johannesburg, Durban and Cape Town."; Rosen and Razin, "Enclosed residential

neighbourhoods in Israel: from landscapes of heritage and frontier enclaves to new

gated communities."; Ploger, "Practices of socio-spatial control in the marginal

neighbourhoods of Lima, Peru."; Caldiera, "Fortified Enclaves: The New Urban

Segregation."; Caldiera, City of Walls.

xx Ibid

${ }^{x x i}$ Agamben, Homo Sacer: Sovereign Power and Bare Life ; Diken and Laustsen, The culture of exception : sociology facing the camp .

Agamben's camp is a contemporary biopolitical paradigm which puts into motion the sovereign's power to suspend law and hence produce 'naked life' in order to defend society. Agamben uses the concentration camp in Nazi Germany as a paradigm to understand the spatialisation of the state of exception. Camp theory has been applied to explain the political space of enclaves in contemporary literature, most notably in work carried out by Diken and Laustsen. This application has received criticisms which are beyond the scope of the paper to discuss. I prefer using camp theory as a descriptor to understand enclaves as biopolitical sites: enclaves usually operate through a state of exception to state laws, usually imposed through an imperative to protect residents within. Emerging rules render life within vulnerable to the new sovereign authority. xxii Graham and Marvin, Splintering Urbanism.

xxiii See the eleven papers within Oliver Coutard's special issue of Geoforum, "Placing Splintering Urbanism"; Stephen Graham, Cities Under Siege.

xxiv Chatterjee, "Violent morphologies: Landscape, border and scale in Ahmedabad conflict."; Davis, Mike. "Fortress Los Angeles: the militarization of urban space."; Angotti,. "Urban Latin America Violence, Enclaves, and Struggles for Land." ${ }^{\mathrm{xxv}}$ Charlotte Lemanski, "A New Apatheid? The Spatial Implications of Fear of Crime in Cape Town, South Africa."

xxvi Diken and Laustsen, The culture of exception : sociology facing the camp.

xxvii Setha M. Low, "Urban Fear: Building the Fortress City."

xxviii Setha M. Low, Behind the gates; Caldiera, City of Wall.

${ }^{x x i x}$ I interviewed users of enclaved space (residents, visitors, service providers, and security professionals), those tied to managennent of enclaved spaces (community 
leaders/members of resident associations, municipal and security governance professionals), and other influential actors such as local political personalities, and experts on urban development and security in Karachi.

xxx The Area Manager has been hired to deal with clerical work and supportive administrative jobs such as forwarding residents' complaints to relevant municipal offices, taking attendance of security and municipal staff working in the area.

xxxi Compiled from field research

xxxii Interview with Saddar Town Administrator on April 28, 2012.

xxxiii Compiled from field research

xxxiv Terms relate to different ethnic groups

xxxv Compiled from field research

xxxvi Compiled from field research

xxxvii Based on Interviews with residents and government officials between June 2011-

September 2012

xxxviii Gupta and Ferguson, "Beyond 'Culture': Space, Identity, and the Politics of

Difference."

${ }^{\text {xxxix }}$ See the various chapters in Keith and Pile, eds. Place and the Politics of Identity;

and in Fincher and Jacobs, eds. Cities of Difference.

${ }^{x l}$ Fincher and Jacobs, eds. Cities of Difference.

xli Alsayyad and Roy, "Medieval Modernity: On Citizenship and Urbanism in a Global Era."

xlii Ibid, p.3

xliii Budhani et al, 2010

\section{Bibliography}

The Dictionary of Human Geography. 5th Edition ed. Chichester, United Kingdom: Wiley-Blackwell, 2009.

Abbas, Hassan. "Reforming Pakistan's Police and Law Enforcement Infrastructure: Is It Too Flawed to Fix?" In Special Report 266: United States Institute of Peace, 2011.

Agamben, G. Homo Sacer: Sovereign Power and Bare Life Stanford University Press, 1998.

Ahmar, Moonis. "Ethnicity and State Power in Pakistan." Asian Survey 36, no. 10 (1996): 1031-48.

Alsayyad, Nezar, and Ananya Roy. "Medieval Modernity: On Citizenship and Urbanism in a Global Era." Space and Polity 10, no. 1 (2006): 1-20.

Angotti, Tom. "Urban Latin America Violence, Enclaves, and Struggles for Land." Latin American Perspectives 40, no. 2 (2013): 5-20.

Benit-Ghaffou, Claire. "Unbundled Security Services and Urban Fragmentation in PostApartheid Johannesburg." Geoforum 39 (2008): 1933-50.

Bishop, Ryan. "Introduction: The Problem of Violence: Megacities and Violence Special Section." Theory, Culture aћ⿹ Society 27 (2010): 3-10. 
Budhani, Azmat Ali, Haris Gazdar, Sobia Ahmad Kaker, and Hussain Bux Mallah.

"The Open City: Social Networks and Violence in Karachi." In, Working Paper No:70 (series 2) (2010).

http://www.crisisstates.com/download/wp/wpSeries2/WP70.2.pdf.

Caldiera, Teresa P. R. City of Walls: Crime, Segregation, and Citizenship in São Paulo. University of California Press, 2001.

. "Fortified Enclaves: The New Urban Segregation." Public Culture 8, no. 2 (1996): 303-28.

Chatterjee, Ipsita. "Violent morphologies: Landscape, border and scale in Ahmedabad conflict." Geoforum 40, no. 6 (2009): 1003-1013.

Coy, Martin. "Gated Communities and Urban Fragmentation in Latin America: The Brazilian Experience." GeoJournal 66 (2006): 121-32.

Davis, Mike. "Fortress Los Angeles: the militarization of urban space."Variations on a theme park (1992): 154-180.

Dick, H. W., and P. J. Rimmer. "Beyond the Third Worls City: The New Urban Geography of South-East Asia." Urban Studies 35, no. 12 (1998): 2303-21.

Diken, Bülent, and Carsten B. Laustsen. The Culture of Exception : Sociology Facing the Camp. Abingdon, Oxfordshire ; New York: Routledge, 2005.

Fincher, Ruth, and Jane M. Jacobs, eds. Cities of Difference. New York: The Guilford Press, 1998.

Gayer, Laurent. "A Divided City: 'Ethnic' and 'Religious' Conflicts in Karachi, Pakistan." In 1st Pakistan Seminar, 1-22. Amsterdam, 2003.

. "Guns, Slums and Yellow Devils: A Geneology of Urban Conflicts in Karachi." Modern Asian Studies 41, no. 3 (2007): 515-44.

Gazdar, Haris, and Hussain Bux Mallah. "Informality and political violence in Karachi." Urban Studies (2013).

Graham, Stephen. Cities under Siege : The New Military Urbanism. London: Verso, 2010.

. "Postmortem City: Towards and Urban Geopolitics." City 8, no. 2 (2004): 16596.

Graham, Stephen, and Simon Marvin. Splintering Urbanism: Networked Infrastructures, Technological Mobilites and the Urban Condition. London: Routledge, 2001.

Gupta, Akhil, and James Ferguson. "Beyond 'Culture': Space, Identity, and the Politics of Difference." Cultural Anthropology 7, no. 1 (1992): 6-23.

Hall, Stuart. Representation: Cultural Representations and Signifying Practices London: Sage, 1997.

Ingram, Alan, and Klaus Dodds. Spaces of Security and Insecurity: Geographies of the War on Terror. Farnham: Ashgate, 2009.

Kieth, M, and S Pile, eds. Place and the Politics of Identity London: Routledge, 1993.

Khan, Nichola. "Violance, Anti-Convention and Desires for Transformation Amongst Pakistan's Mohajirs in Karachi." Cultural Dynamics 22, no. 3 (2010): 225-45. 
---------. "Between Spectacle and Banality: Trajectories of Islamic Radicalism in a Karachi Neighbourhood." International Journal of Urban and Regional Research 36, no. 3 (2011): 568-84.

Koonings, K, and D Kruijt, eds. Fractured Cities: Social Exclusion, Urban Violence and Contested Spaces in Latin America: Urban Violence, State Failure and Social Exclusion London: Zed Books, 2007.

Koonings, Kees, and Dirk Kruijt. Mega-Cities: The Politics of Urban Exclusion and Violence in the Global South. London: Zed Books, 2009.

Lemanski, Charlotte. "Global Cities in the South: Deepening Social and Spatial Polarisation in Cape Town." Cities 24, no. 6 (2007).

"A New Apatheid? The Spatial Implications of Fear of Crime in Cape Town, South Africa." Environment and Urbanization 16, no. 2 (2004): 101-12.

Low, Setha M. Behind the Gates : Life, Security, and the Pursuit of Happiness in Fortress America. New York: Routledge, 2003.

_. "Urban Fear: Building the Fortress City." City and Society 9, no. 1 (1997): 5371.

Malik, Iftikhar. H. "What Is Wrong in Karachi." Economic \& Political Weekly 33 (1998): 2219-21.

Mercer. "Quality of Living Worldwide Rankings- Mercer Survey." http://www.mercer.com//pressrelease/details.htm?printerfriendly=true\&idConte $\mathrm{nt}=1173105 \& \mathrm{eu}=\mathrm{null}$.

Moser, Caroline. "Coping with Urban Violence: State and Community Responses to Crime and Insecurity in Guayaquil, Ecuador." Chap. 4 In Mega-Cities: The Politics of Urban Exclusion and Violence in the Global South, edited by Kees Koonings and Dirk Kruijt. 69-81. London: Zed Books, 2009.

Norton, Richard J. "Feral Cities." Naval War College Review LVI, no. 4 (2003): 96-106.

Perlman, Janice. "Megacity's Violence and Its Consequences in Rio De Janeiro." Chap. 3 In Mega-Cities: The Politics of Urban Exclusion and Violence in the Global South, edited by Kees Koonings and Dirk Kruijt. 52-68. London: Zed Books, 2009.

Sassen, Saskia. "When the City Itself Becomes a Technology of War." Theory, Culture and Society 27, no. 6 (2010): 33-50.

Sidaway, James D. "Enclave Space: A New Metageography of Development?". Area 39, no. 3 (2007): 331-39. 